流れの可視化 Vol.6 No.22 (1986年7月)

\title{
31 流机の可視化に上当洞流の計测
}

\author{
京都大学工学部顺洋典 \\ Measurement of velocity fields of a vortex flow \\ using a visualization technique
}

Yosuke KAWANO*

A vortex flow was generated by means of a stream of air bubbles released at the center of upper part of the rotating tank. The basic velocity measurements were made by photographing the motions of small marker particles and analysing time-exposure pictures.

It is obvious from these experimental results that the flow can be significantly influenced on the boundary conditions at both the top and bottom of the vortex. The vortex flow is confined to a cylindrical region which is composed of a spiral upward flow in the center surrounded by an annular downflow.

\section{1.住しめ上}

台風や童巻のシミレーションとして、これまで

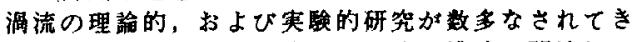
た.1)また最近，乱流境界層の流れ槽造に関連して 境界壁近傍に発生する㭌洞が乱流の秦過程としの秩 序掅造を示㖫するものとして注目されている。2) しかし，これら洞流の，特にその定性的な特性は 3 次元搏造からくる困雎さのために充分把暒されてい ないように思わ机る。

ここでは，回転する液体（壒水）の中に空気を送 りこみ，その気泡が軸方向の伸長流を誘望し，洞流 を造りだす手法を棌用した。そして、トレサー法に よって流れを可梘化し，粒子の勒跡から間接的に洞 流の速度分布を求めた。その䊅果, 洞流は自由表面 や境界の影翌を大きく受け，安定した瀜流を得るた めには実验装置に種々の工夫をこらす必要があった

また，流速分布は满足な䊅果とはいえないが，漫 流の䏆造を把握することができた。

\section{2. 方法}

2.1 実酸装宜 回転する容器の中に安定した 渦流を造りだすためにFI G、1に示すようす実䮲 装置を用いた。容器は直径 $32 \mathrm{c} \mathrm{m}$, 深さ $45 \mathrm{c} \mathrm{m}$

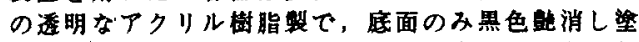
装されている，容器の上部中心部に空気気泡を送り こむたかのノスルが取り付けてられている。图に示

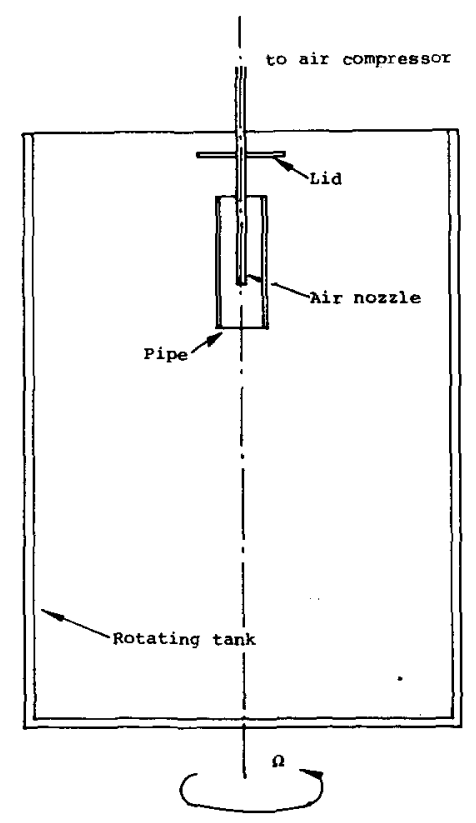

Fig. I Rotating tank

* Faculty of Engineering, Kyoto University; Yosida-honmachi,Sakyoku,kyoto 606 


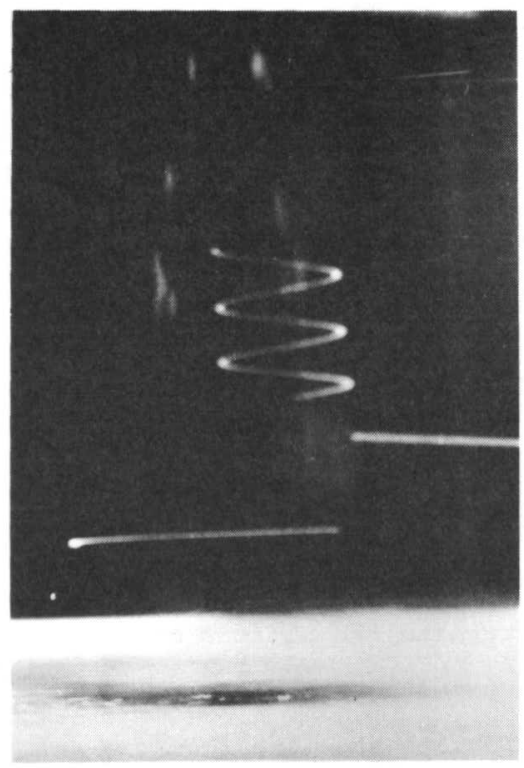

Fig.2 Photograph of particle streaks

すようにこのノズルは気泡が流れ全体を乱さない よjに直径 $3 \mathrm{c} \mathrm{m}$, 長さ $10 \mathrm{~cm}$ のパイプで覆われ ている、さらにまた，気泡が流体の自由表面を乱す のを出来るだけ防ぐために自由表面のすぐ上に気泡 を消すための板蓋が取り付けられている。これらの 装置全体が回転台の上に取り付けられていて, 角速 度 $0-10 \pi \mathrm{r}$ a d / $\mathrm{s}$. の範囲で任意に制御する ことが出来る.

2. 2 流れの可視化 流速を測定するため にトレサーとして球状のポリスチレン粒子を用い渦 流を可視化した。作動流体はポリスチレン粒子と密 度を一致させるため，水に食塩を溶かし比重が
1. 034 （水温 $20 \quad$ C) になるように調節 された。

容器上部から强いライトを照射し, ポリスチレン

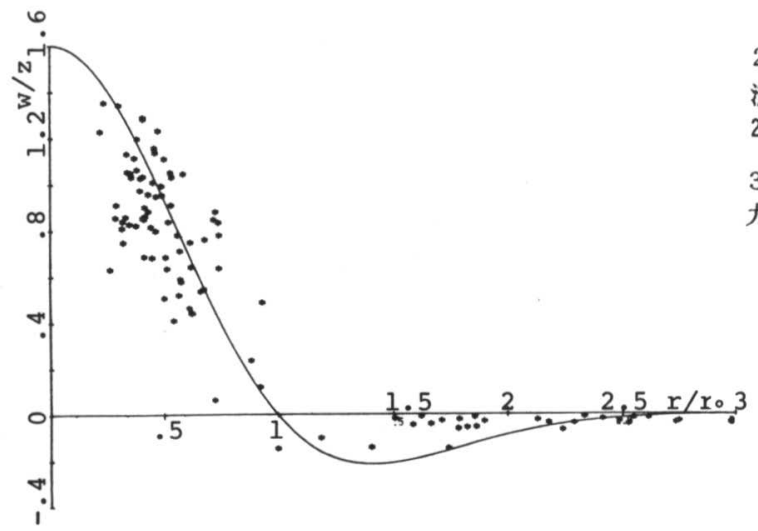

Fig. 3 Vertical velocity distribution

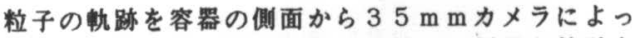
て写真撮影した。ポリスチレン粒子は鮮明な勒跡を

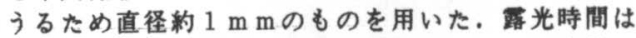
0. 5 秒から 4 秒まで流速の大きさによって変化さ せた，F I G。2 2 は底面からの高さ約 $5 \mathrm{c} \mathrm{m}$, 露光 時間 0.5 秒での粒子の軌跡を示したものである。

2.3 流速测定 写真撮影された粒子の俚跡は ネガのまま大きく引き伸ばされ, グラフ用紙に記入 された後, 上下の位置, 蝶旋の直径, 回転角度をデ シタイザーで読み取り計算機で処理する。また，容 器が透明な円简形であるため, 維横の倍率, 視差を あらかじめ㭪正しておく、しかし，F I G，2に示 すような粒子の軌跡からは粒子の移動方向を判断す ることは出来ない，そこで, 粒子の移動方向はカメ ラのファインダーをとおして個々に判断した。

\section{3 結果と考察}

実驗は容器の回転角速度が0.624 r a d / s の場合について行なったＦｉｇ．３は回転䌷方向 の速度分布を示している. 図中の実線は最近, $\mathrm{T}$ a

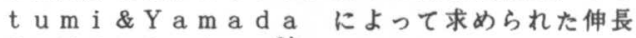
㵝の速度分布である. ${ }^{3)}$

渦流の樓造はその中心部に軸に沿うジェット状の 流れがあり，それを取りまくように逆流する部分が 存在する。また流れ全体は回転軸を中心として比較 的狭い範囲に集中していることがわかる。

ポリスチレン粒子の軌跡から間接的に流速を求め るこの方法は渦流の中心部および逆流を生じる部分 で計測が困難になる欠点がある。しかし，概略の速 度分布を比較的简便に求めることが出来る点は評価 出来る. 测定点にバラッキが多いことは今後充分検 討する必要がある。

参考文献

1) TURNER, J.S. The constraints imposed on tornado-like vortices by the top and bottom boundary conditions, J.Fluid Mech. 25(1966) $377-400$

2) 大成博文, 佐賀考德, 山本恭子, 斎藤降: 壁乱 流における䜯渦の可視化, 流れの可視化, 14(1984) 233-238

3) 哄 友正: 流れと焵と乱流れ, 第 16 回 流体 力学潇演会 (1984) 206-214 